\title{
High North, Low Politics-Maritime Cooperation with Russia in the Arctic
}

\author{
Andreas Østhagen ${ }^{\star}$, \\ Research Fellow, Norwegian Institute for Defence Studies, Norway, and PhD-fellow, \\ University of British Columbia, Canada
}

\begin{abstract}
Maritime activity is increasing in the Arctic. So is bilateral cooperation across maritime borders between coast guards intent on protecting natural resources, saving lives and assisting navigation. As tensions rose between Russia and the West in 2014, due to the conflict in Ukraine, coast guard cooperation in the Bering and Barents Seas was unaffected. Why? How did the respective bilateral cooperative structures between Norway/the United States and Russia develop, and why were they deemed "too vital to cancel" in the aftermath of events in Ukraine? This article examines how the respective states have developed cooperative regimes since the 1970s, and subsequently how these regimes have come to constitute the backbone of bilateral management of these vast and invaluable maritime domains. The argument made is that the specific character of coast guards and their role as stewards of the sea separate them from other military structures, making bilateral cooperation not only valuable, but indispensable, to the management of the states' maritime sovereignty.
\end{abstract}

Keywords: Russia; coast guards; maritime cooperation; Arctic security; regime building; maritime security

Received: December 2015; Accepted: March 2016; Published: May 2016

\section{Introduction}

As the relationship between Russia and the West deteriorated in 2014, military-tomilitary contact between the parties was halted. Exercises and planned meetings were cancelled or postponed, and economic sanctions were put in place. Yet, for those western countries sharing land or maritime borders with Russia, certain concessions had to be made. Domains where direct contact was deemed essentialsuch as border and coast guard services-were kept in place. Due to its territorial

${ }^{\star}$ Correspondence to: Andreas Østhagen, Norwegian Institute for Defence Studies, Kongens gate 4, 0104 Oslo, Norway.

This article is part of the research program Security and Defence in Northern Europe (SNE), led by the Norwegian Institute for Defence Studies (IFS) and funded by the Norwegian Ministry of Defence. For insightful comments and invaluable feedback, I would especially like to thank Robin Allers, Paal Sigurd Hilde, Håkon Lunde Saxi, Roald Gjelsten, Rolf Tamnes, Kristine Offerdal, Sven Holtsmark, Geir Hønneland, Olav Schram Stokke, Elana Wilson Rowe, Marc Lanteigne, Michael Byers, and two anonymous reviewers. 


\section{A. Osthagen}

vastness, Russia shares a maritime boundary with a total of 14 countries. ${ }^{1}$ The most prominent in terms of length and maritime space are it boundaries with Japan, Norway and the United States (US), of which the two latter are found in the Arctic. This article examines the status and role of coast guard cooperation with Russia in the Arctic, and the extent to which Norwegian-Russian and U.S-Russian cooperation in this field has been affected by recent changes in the international geopolitical environment. How did the bilateral coast guard cooperation with Russia in the Barents and Bering Seas develop? And why was this particular domain not cancelled after the decision to suspend military-to-military cooperation with Russia in 2014?

The two cases and maritime areas in question - the Barents Sea and the Bering Sea - are subject to the changing conditions in the Arctic. With rapidly melting seaice and increased maritime traffic in the region, all Arctic coastal states have placed emphasis on cooperation to help remedy some of the capacity challenges faced. This is particularly relevant for the countries' coast guards, which often constitute the bulk of - if not the only — public asset available in the maritime Arctic. The Barents and Bering Seas are therefore a remarkable case study of maritime cooperation, where Russia borders two continents in two different maritime regions. Beyond the growing centrality of the Arctic, the interesting aspect of this topic is the impact - or lack thereof - of the conflict over Ukraine on maritime cooperative schemes. To be able to examine this, we therefore need to study the traits of the different cooperative regimes and how they have developed over the last decades.

The argument I make is that upholding cooperation between coast guards is a consequence of the unique character of coast guards themselves, and the specific nature of the cooperative mechanisms that have developed through decades of regional interaction. Beyond the virtue of maintaining dialogue, the vitality of this specific form of cooperation lies in its intrinsic relationship with so-called 'soft' security tasks in the coast guards' role as maritime stewards, stretching beyond - and in this instance even surpassing - the military security concept. ${ }^{2}$ Additionally, due to the meticulous low-level regime-building that has been taking place in the Arctic between Russia and its two maritime neighbours, along the lines of so-called "lowpolitics," the cost of cancelling cooperation was deemed higher than the benefits of a strong symbolic response in reaction to Russian actions in Ukraine. To rephrase a slogan coined in Norway, ${ }^{3}$ maritime cooperation in the Arctic can best be described as "high north, low politics."

The article is based on a number of background interviews conducted with officials from the two coast guards and historical data gathered on coast guard affairs. It relies heavily on empirical data from, and research on, the two regions, while making limited use of a theoretical framework. As such, it does not claim to expand the theoretical debate on bilateral cooperation between states. The article is also only concerned with the Norwegian and the American coast guards' approach to these issues, omitting Russian interests and perceptions, which is arguably a limitation Yet, studying how two Arctic coastal states - albeit of very different size and international status - cooperate with an increasingly expansive maritime neighbour in a time of constrained relations, should be of relevance to the study of international affairs at large. 
In the case of the Barents Sea, researchers like Hønneland, Stokke and others have provided ample historical data and analysis to be used in an historical comparison. The lack of in-depth research on maritime cooperation between the US and Russia in the Bering Sea, however, provides a challenge. This article, therefore, makes an important contribution to the expansion of knowledge on this particular region, while also placing both the Barents Sea and the Bering Sea regimes in a new context. It thus brings forth new knowledge by comparing and contrasting these two cases, against a backdrop of a disruptive contemporary geopolitical event.

The following article first examines the two cases of bilateral coast guard cooperation, including a brief overview of the effects of the Ukraine crisis. In turn, this allows us to examine why coast guard cooperation was sheltered, articulated along the dimensions of (1) regime-building and (2) ocean stewardship. Thereafter, we draw some conclusions, returning to the question of why coast guard cooperation was sheltered in the first place.

\section{Maritime Cooperation in the Arctic}

\subsection{The Barents Sea}

The Barents Sea is located north of the Norwegian and Russian mainland, just off the Arctic Ocean itself. The maritime area covers approximately 1.4 million square kilometres (540,000 square miles). Its boundaries are set by the Svalbard archipelago (Norway) to the west, Franz Josef Land (Russia) to the north, Novaya Zemlya (Russia) to the east, and the European continent (mainland Norway and Russia) to the south. The Sea is named after the Dutch explorer Willem Barentsz, who ventured northwards in search of a sea route to Asia via the northern hemisphere in the late 16th century. When Norway and Russia established their 200 nautical mile exclusive economic zones (EEZs), in 1976 and 1977 respectively, a dispute concerning the maritime boundary between the two countries in the Barents Sea arose. The size of the disputed area was approximately 175,000 square kilometres. An agreement concerning the disputed area, the so-called "Grey Zone Agreement", was signed in 1978 and was renewed annually up until 2010. The agreement recognized the countries' rights to fisheries in the area, without tackling the legal dispute itself. In 2010 - after 33 years of negotiations - Norway and Russia agreed on a joint maritime border more or less dividing the disputed area in half. ${ }^{4}$

The Svalbard archipelago is a somewhat different story. In 1977, Norway established a Fisheries Protection Zone (FPZ) around the archipelago. Under Norwegian jurisdiction, granted by the Svalbard Treaty from 1920, Norway claims that the 200-mile zone around Svalbard is part of the Norwegian EEZ, as this innovation in maritime law did not exist when the Treaty was formalised in 1920 . Russia - amongst others - claims that the principles of the Treaty should apply to the 200-mile zone as well, thereby granting all signatories equal right to economic activity in the water column. To avoid an outright challenge to the Norwegian claim and to protect and manage what is the central nursery area for the Northeast Arctic 


\section{A. Osthagen}

cod stock, the Norwegian government established a FPZ. ${ }^{5}$ The other Treaty signatories have so far accepted this, although Russia and Iceland in particular have been outspokenly critical of what they perceive to be discrimination of foreign fishing vessels in the area by the Norwegian coast guard.

In terms of economic activity, the Barents Sea is the breeding and nurturing place for the largest cod stock in the world, the Northeast Arctic cod, which has been one of the main reasons for subsistence along the North Norwegian and Northwest Russian coasts. ${ }^{6}$ The Sea is also rich in a number of other marine species that have fostered economic activity, like shrimp, whale, seal, and of late, king and snow crab. In the 1970s, cooperation between Norway and Russia on fisheries in the Barents Sea developed pragmatically, in response to the establishment of the EEZs and the subsequent maritime boundary dispute. An agreement between Norway and the former USSR on fisheries in the Barents Sea was completed in 1975, and the first Joint Fisheries Commission between the two countries convened in 1976. The Commission's emphasis was on scientific research to ensure sustainable management of the stocks. ${ }^{7}$ Since 1979 , seismic surveying and exploratory drillings have also taken place in the Barents Sea. On the Norwegian side, Statoil has produced Liquefied Natural Gas (LNG) from the Snøhvit gas field since 2006, and ENI is set to start producing oil from the Goliat field in 2016. Activity on the Russian side has been at a lower level, as there are more easily accessible commercial resources to extract onshore/near offshore in the Yamal/Nenets region further east. ${ }^{8}$ As petroleum exploration in the Barents Sea expanded and the Cold War ended, Russia and Norway agreed on an oil spill agreement in 1994, which included developing joint contingency plans and procedures for notification in the event of an oil spill. ${ }^{9}$ Search and rescue cooperation was initially based on an agreement from 1956, which was renewed in 1988 and $1995 .^{10}$

Practical cooperation between the coast guards, however, did not expand until the 1990s. ${ }^{11}$ After the Soviet Union collapsed, Russian fishermen started overexploiting the Barents cod stock, and in 1992 the Joint Fisheries Commission expanded their mandate to include control measures. Routines for sharing information on catches and quotas were subsequently established. ${ }^{12}$ By 2000, cooperation had further developed and a Memorandum of Understanding (MoU) was signed between the two countries, outlining a number of cooperative measures. The MoU has been revised at times, with current version dating from 2013. It draws up a range of areas where the countries can share information, concerning illegal activity, fisheries inspections, quotas and practical experiences. ${ }^{13}$ An additional-and substantialpart of the coast guard cooperation involves the mutual exchange of fisheries inspectors and operational personnel. Coast guard personnel thus meet with their Russian or Norwegian counterparts to learn procedures, exchange experiences and establish personal relations.

These various measures of relatively in-depth cooperation have derived from the need to jointly manage the fish stocks in the Barents Sea, to the benefit of both Norway and Russia. As such, coast guard cooperation has expanded to deal with a growing number of challenges: initially the increase in unregulated fisheries and 
subsequently a wide range of coast guard tasks relating to search and rescue, oil spill prevention and response, and management of marine resources, as maritime activity levels in northern waters are increasing. The Joint Fisheries Commission in particular is a highly relevant tool for managing fisheries affairs between the two countries, and is often described as a success story. ${ }^{14} \mathrm{With}$ an increase in northern maritime traffic, the coast guards are forced to devote more resources to handling potential challenges. As fisheries grow in volume, so does the demand for fisheries inspections conducted by the coast guards on behalf of their national authorities. As the number of cruise liners increase, so does the need for systems that can handle a potential search and rescue incident. Similarly, in ice-covered parts of the Arctic (in this case in Russia), the demand for aid to navigation-sometimes requiring ice breaking - has increased. ${ }^{15}$ These challenges have prompted a desire to explore mutually beneficial arrangements in the Barents Sea, as elsewhere. Russia and Norway are also intent on cooperating on matters of the North East Atlantic Fisheries Commission (NEAFC), the organization set to manage quotas and rights to conduct fisheries in the North East Atlantic international waters. ${ }^{16}$

In spite of this, complete harmony does not prevail between Norway and Russia in the Barents Sea. The Russian Coast Guard has, on occasion, suggested that Norway and Russia conduct joint fisheries inspections in the FPZ around Svalbard. ${ }^{17}$ Such cooperation would challenge Norwegian sovereignty and authority in the FPZ, and the Norwegian Joint Headquarters has firmly declined all such proposals. ${ }^{18}$ Russian fishing vessels inspected by the Norwegian Coast Guard in the FPZ also refuse to sign the inspection documents as a symbolic gesture to highlight how Russia does not recognize Norwegian authority in the Zone-although they allow the Norwegian Coast Guard to perform inspections of the vessels. After the maritime boundary delimitation agreement in 2010, there have also been voices in Russia claiming the deal is too favourable to Norway. These sentiments have, however, yet to lead to a marked change in the bilateral relationship between Norway and Russia in the Barents Sea. ${ }^{19}$

\subsection{The Bering Sea}

The Bering Sea is the maritime area south of the Bering Strait, where the United States and Russia share a maritime border. This maritime space covers approximately 2.3 million square kilometres (890,000 square miles). Its boundaries are determined by the state of Alaska (United States) to the east, the Kamchatka Peninsula and Chukotka Autonomous Okrug (Russian Federation) to the west, and the Aleutian Islands (Russian Federation and United States) to the south. The Sea is named after Vitus Jonassen Bering, a Danish explorer in the service of the Russian Navy, who set out to explore the maritime region towards the Bering Strait in 1728 . When the United States purchased Alaska from Russia in 1867, the maritime boundary in the Bering Sea/Strait area was defined, albeit without clearly determined map lines and two interpretations of the line itself, namely the rhomb line (Russia) and the geodetic line (US). This led to a dispute between the USSR and the US in 1977, as the two countries extended their maritime zones to 200 nautical miles 


\section{A. Osthagen}

where possible. The conflict caused an overlapping disputed area of approximately 39,000 square kilometres (15,000 square miles). ${ }^{20}$ In 1990, the USSR and the US agreed to a settle the maritime boundary, known as the Baker-Shevardnadze agreement. ${ }^{21}$ It also established so-called "special areas" outside the 200 nautical mile zones and the open international waters area between the two countries, known as "the Donut Hole". ${ }^{22}$ The US Congress ratified the agreement in 1990, but after the collapse of the USSR at the end of 1991, the new Russian Duma subsequently never ratified it.

Since then, Russian politicians and fishermen have criticized the agreement, arguing it is in disfavour of Russian fishing interests in the Bering Sea, as Russia ceded more of the formerly disputed area than the US. ${ }^{23}$ Since 1990, The US, through the US Coast Guard, has enforced the new maritime boundary to continue to build general state practice. At times, this has led to clashes between the US Coast Guard and Russian fishing vessels intent on fishing along the maritime border. ${ }^{24} \mathrm{At}$ low levels, but more or less regularly, Russian fishing vessels have breached the maritime border and been observed by the US Coast Guard inside the US EEZ. ${ }^{25}$ The fishermen see these breaches as a challenge to the maritime border, arguing they have been "expelled" from their own waters where they have rights to fisheries. ${ }^{26}$ The regional bilateral relationship since the 1990s has been dominated by this issue, with the US Coast Guard having to deal regularly with Russian trawlers. ${ }^{27}$

The Bering Sea, like the Barents Sea, is home to a number of marine species of significant economic value, such as: cod, pollock, salmon, king and snow crab, seal, and whale. In the Bering Sea at large, and in the Donut Hole in particular, many of the fish stocks have been subject to overfishing, in particular the Alaskan pollock. As in the Barents Sea, the expansion of overfishing prompted negotiations between the former USSR and the US in the 1980s. In 1988, an agreement on mutual fisheries relations was signed between the two parties. The agreement established a consultative committee on fisheries in the Bering Sea. ${ }^{28}$ Constituting the most lucrative fisheries in North America, the pollock stock collapsed in the early 1990s, after a decade of overfishing in the Donut Hole. ${ }^{29}$ An agreement on a temporary moratorium with stringent enforcement measures on pollock was reached between the various national stakeholders in 1994, including Japan, China, Poland and South Korea. ${ }^{30}$

Concerning oil and gas development, the Bering Sea has not seen the same level of activity as in the Barents Sea. In 1989, pre-empting expected offshore petroleum activity by Shell planned for the early 1990s, the USSR and the US signed the Agreement Concerning Cooperation in Combating Pollution in the Bering and Chukchi Seas in Emergency Situations. ${ }^{31}$ Shell drilled exploratory wells in the Chukchi Sea north of the Bering Strait in the 1990s, but the most promising areas for petroleum development in the Bering Sea-the Aleutian Basin —was placed under moratorium after the Exxon Valdez oil spill in 1989. Although the moratorium was lifted in 2007, no new activity has taken place since. ${ }^{32}$ In the Far East Russian regions, oil and gas activity has focused on near-shore developments at Sakhalin, in the Sea of Okhotsk. With regard to search and rescue, a 1972 agreement between the US and the USSR on prevention of incidents on and over the high seas, initially set 
out procedures for safety and cooperation in the Bering Sea. Similarly, the two parties signed an agreement the same year on environmental research and nuclear protection.

More recently, the US has placed emphasis on developing a well-functioning cooperative relationship with the Russian Coast Guard, as traffic in the Arctic is on the rise. Most of the traffic increase in these waters derives from Arctic shipping or shipping to destinations in the Arctic itself, as a means of resupplying isolated coastal communities or with the purpose of bringing natural resources to markets further south. ${ }^{33}$ Efforts to reduce overfishing - particularly from third party countries active in the Donut Hole - have been expanded. For example, the two coast guards cooperate on requests to identify unknown vessels operating in the Donut Hole, to enforce the 1994-agreement on pollock. As concern over increased traffic through the Bering Strait surfaced on the public agenda in 2007-2008, a number of articles and public documents from the US Government highlight the need for cooperation with Russia to manage the narrow chokepoint of the Bering Strait. ${ }^{34}$ As highlighted by Byers and Baker, Russia approached the US in 2009, suggesting a range of Bering Strait initiatives to deal with the potential increase in traffic and the environmental risk that follows. ${ }^{35}$ Other examples of new areas of potential cooperation range from fuel assistance to icebreaking support and information gathering.

Building on the 1988-agreement, negotiations on fisheries have continued annually from 2008 onwards between the US and Russia, with the aspiration of achieving a wider and more comprehensive agreement. Consequently, in 2013, the two countries issued a joint statement on strengthening US-Russian cooperation to combat illegal, unreported and unregulated (IUU) fishing activity in the Bering Sea. ${ }^{36}$ Similarly, based on the desire to implement the multilateral agreements signed under the auspices of the Arctic Council in 2011 and $2013,{ }^{37}$ the regional US Coast Guard authority from District 17, Juneau Alaska, met with their Russian counterparts in Vladivostok, Primorsky Krai, in 2013. The goal was to discuss expansion of coast guard cooperation, looking to start annual joint exercises in the Bering Sea/ Strait region by $2014 .^{38}$ The White House Implementation Plan for the National Arctic Strategy from January 2014 follows up on this and highlights the need to continue oil spill preparedness and response coordination with Russia, in order to develop joint response seminars and exercises by the end of $2015 .^{39}$

\subsection{The impact of the conflict over Ukraine}

As relationships deteriorated between Russia and the other Arctic states in 2014, it became increasingly difficult to shelter Arctic affairs from the larger security environment. ${ }^{40}$ Acting in accordance with the NATO Alliance, both the US and Norway disbanded military-to-military relations with Russia in March 2014. Official military dialogue and joint military exercises in the Arctic were consequently cancelled or postponed indefinitely, as the conflict continued to evolve with Russian military actions in Eastern Ukraine. ${ }^{41}$ At a NATO summit in Cardiff in September 2014, the member states adopted continued suspension of all practical and military cooperation between the Alliance and Russia. This had an impact on cooperation 


\section{A. Osthagen}

with Russia in the Arctic, as meetings to discuss northern security affairs were postponed and military activity in the north came under new scrutiny. ${ }^{42}$ Yet, what was the effect on coast guard cooperation in the Barents and Bering Seas specifically?

As relations deteriorated, discussions concerning the joint exercises and operationalization of the Arctic Council agreements between the US and Russia initially came to a halt. The IUU-negotiations, as well as the proposition of joint Bering Sea exercises the same year, were postponed. In the Barents Sea, the biannual exercise Northern Eagle between the US, Norway and Russia was cancelled in 2014. Similarly, the bilateral military naval exercise Pomor, between Norway and Russia, was also cancelled. This exercise had been reconvened back in 2010, to highlight how the armed forces in Norway and Russia could jointly solve challenges arising in the Arctic. ${ }^{43}$ In a multilateral context, representatives from the Russian coast guard could not obtain visas to participate in two Arctic Coast Guard Forum expert meetings in Sydney, Canada, in 2014, and the establishment of the Forum was placed on hold.

However, after an initial halt in cooperation, relationships on coast guard affairs in the two cases quickly resumed normality. Multilaterally, another meeting to discuss the establishment of the Arctic Coast Guard Forum was held in March 2015-this time hosted by the US in Washington DC. And in October 2015, the Forum was formally established between all eight Arctic states, again with the US as host in Connecticut, with the Russian Coast Guard Chief present. ${ }^{44}$ During this process, both Norway and the US stressed the need to keep political channels open and practical cooperation in their maritime border areas unharmed. For example, when a South Korean fishing vessel with 60 crew on-board sunk in the Bering Sea 109 nautical miles off the Russian coast of Chukotka on November 30, 2014, the Russian Kamchatka Border Guard District requested US Coast Guard assistance. Several US Coast Guard assets participated in the search for survivors, under Russian coordination. ${ }^{45}$ On the bilateral level, the work on an IUU-agreement between Russia and the US progressed, and was signed in September 2015. ${ }^{46}$ In the Barents Sea, the Norwegian authorities also placed considerable emphasis on the importance of continuing cooperation and dialogue with Russia, as relations grew tense. ${ }^{47}$ Cooperation on coast guard affairs, border guard services and emergency response were upheld, while dialogue between the Chief of the Russian Northern Fleet and the Chief of the Norwegian Joint Military Headquarters still continued on a weekly basis. The "Barents"-exercise, which targets coast guard and rescue tasks specifically, similarly took place in both 2014 and 2015. The purpose of these exercises is to enhance search and rescue capabilities and oil spill preparedness in the High North.

In sum, Russian actions in Ukraine have no doubt had an effect on bilateral and multilateral cooperation in the Arctic. Norway and the US cancelled military exercises that would have included components focused on "softer" security - or safety-concerns. Canada's hard line towards Russia also hampered the establishment of a coast guard-specific forum for the Arctic in 2014. At the same time, both Norway and the US saw the necessity of maintaining a practical working relationship with their Russian counterparts in their respective border areas. The US also took 
leadership in the process of finally establishing an Arctic Coast Guard Forum in late 2015. Albeit strained, coast guard relationships thus quickly normalized despite tension elsewhere. The question is: Why?

\section{High North, low politics}

In 1966, Stanley Hoffmann coined the distinction between "high" and "low" politics, as a way of separating the different policy-spheres of European integration. Economic policy constitutes "low politics," whereas the survival of the state, i.e. security policy, constitutes "high politics." 48 In spite of its critique, ${ }^{49}$ pioneering scholars in the field of Arctic state relations, like Oran Young and Willy Østreng, have made use of Hoffmann's distinction to highlight how certain areas of "low politics"like environmental policy or Arctic shipping - have allowed states to cooperate in spite of rivalry in the domain of "high politics." 50 We can observe the same trend with regard to coast guard cooperation in the Bering and Barents Seas. The previous sections describe how cooperation on coast guard affairs has been a topic of relatively low political engagement. It has-more or less-been left to the coast guards themselves, and the various commissions established to deal with fisheries (supported by the foreign ministries). This cooperation has also been seen as a minor, yet important, component in the larger bilateral relationships with Russia, although it has received increasing attention in recent years. The differentiation between high and low politics entails a hierarchy, as some policy issues undoubtedly receive more attention than others by policy makers. As such, coast guard cooperation has been kept separate from other military and security concerns through (1) regime-building between coast guards and (2) focusing on tasks related to stewardship or "soft" security. The following sections examine these two dimensions.

\subsection{Regime-building}

The most standard definition of an international regime is "a set of implicit or explicit principles, norms, rules, and decision-making procedures around which actor expectations converge in a given area of international relations". 51 The extent to which expectations have converged in the Barents and Bering Seas is debatable. There is also a lack of consensus in the literature on whether or not convergence actually takes place between cooperating states. ${ }^{52}$ Yet, in this context, both maritime regions highlight how a mutual interest in dealing with issues led to the establishment of cooperative mechanisms between the states in question. As international negotiations concerned with the extension of maritime EEZs were finalized in the 1970s and 1980s, the demand for cooperative mechanisms in the Bering and Barents Seas increased. Described in the previous section, efforts to deal with migrating fish stocks and joint emergency preparedness and response were developed between the US and the USSR, and Norway and the USSR, as the countries claimed their new maritime boundaries.

Yet, it was not until towards the end of the Cold War that such measures were further formalized. The Joint Fisheries Commission between Norway and Russia 


\section{A. Osthagen}

expanded its mandate in the 1990s. The maritime border between the USSR/Russia and the US was settled in 1990, while an agreement on "Donut Hole" fisheries was agreed upon in 1994. At the start of the new millennium, cooperative measures in these regions were given new attention, as focus fell on the Arctic as a global "hotspot." In Norway, the elevation of the Arctic as the number one strategic foreign policy priority coincided with the failed arrest of the Russian trawler "Elektron" in 2005, and the subsequent focus on maritime activities in the Barents Sea. In the United States, Arctic affairs came to the fore in tandem with Shell's offshore efforts in the Chukchi Sea. ${ }^{53}$ Focus turned to enabling the US Coast Guard to deal with an expected increase in maritime traffic, while the US Arctic Council chairmanship has placed ocean governance at the top of the agenda. ${ }^{54}$ Many of the US's efforts have targeted Russia specifically, with an aim to expand cooperative measures between the two countries. Norway and the US have thus both placed weight on the maritime dimension of their Arctic engagement, in which Russia holds an integral role.

It is, however, important to recognize that Norway and the United States place varying degrees of weight on coast guard collaboration with Russia, and operate as two very different entities on the international stage. Norway is, by most definitions, a state with limited capacity and influence. ${ }^{55}$ This is not to discount that Norway has capabilities in certain domains, where the country's reputation, wealth and geography come into play. Yet, Norway is still lilliputian in relation to its larger Russian neighbour. ${ }^{56}$ While Norwegian security doctrine is deeply embedded in its transatlantic partnership with the US, being a neighbour with Russia entails cooperation on everything from environmental to border issues. Neighbour relations between Norway and Russia are thus defined by having the ability to do two things at once: upholding territorial integrity and protecting sovereign rights, while also maintaining civil relations and engaging in cooperative local and regional schemes. For Norway, the Barents Sea is therefore an area of both bilateral cooperation and security concerns.

Compared to the US, Norway's ability to exert global influence is limited. The variation in size and influence between the two countries translates into differences in each country's relations with Russia. The US-Russian border in the Bering Sea/Strait region arguably does not constitute the most prominent security concern for the US. With global outreach and worldwide entanglements, the border to the north has lost much of its geopolitical significance since the end of the Cold War. ${ }^{57}$ This is not to say that the maritime border does not hold importance, particularly on a regional level for Alaska and for commercial activity in the region. Yet, this northern state and the relatively sparsely populated Chukotka Okrug do not constitute predominant security concerns for decision-makers in Washington, DC. ${ }^{58}$ US policy is global, and in this context, coast guard cooperation with Russia does not hold the same prominence as it does for Norway.

At the same time, both Norway and the US deliberately chose to shelter this form of cooperation as bilateral relations with Russia deteriorated in 2014. To explain this, we have to examine the regime-building that has been taking place in both regions. In both cases, as bilateral relationships developed over the decades, regimes were 
slowly established to formalize contact. Albeit relatively ad-hoc or issue-specific, continued dialogue on fish stock management and emergency response constitute the backbone of this contact. Consequently, bilateral regimes developed between the parties. An important aspect of this regime-building has been the practical approach taken by the actors, avoiding issues that risk becoming dominated by overarching political concerns. As both Hønneland and Stokke argue in their research on the Barents Sea, ${ }^{59}$ this has occurred through relationship-building over decades, predominantly on a practical level between the coast guards themselves, or between officials participating in the Joint Fisheries Commission.

Whereas bilateral relations between the Norwegian and Russian coast guards in the Barents Sea have developed predominantly due to fisheries, bilateral relationship-building has not developed at the same pace between Russia and the United States. Correspondingly, there have been fewer studies of Russian/American maritime cooperative regimes in the Bering Sea, partly due to the limited extent of this cooperation. ${ }^{60}$ This is not to say that there has not been bilateral contact between the two countries. There are a number of examples of the coast guards assisting each other and exchanging information on relevant topics. The US Coast Guard regularly requests Russian assistance in dealing with trawlers operating in the border area, and the coast guards frequently exchange information concerning traffic and fisheries activity. Compared, however, to the growth in cooperative measures in the Barents Sea, regime-building in the Bering Strait seems to have been kept at a more informal and case-to-case level. ${ }^{61}$ Geography and demography can help explain this difference. Norway and Russia share a land border, in addition to a maritime border, and the area is more densely populated than its North Pacific counterpart. The sheer geographical distance between Russia and the US in the Bering Sea, in combination with relatively low levels of maritime activity, entails a different level of cooperation. Consequently, there has been more contact between the parties in the Barents Sea, resulting in measures such as the exchange of fisheries officers and more frequent use of joint exercises.

In sum, when comparing and contrasting these two cases of regional low-level regime-building, it is important to recognize that Norway and the US differ with regard to the emphasis they place on their maritime borders with Russia. Yet, in both cases, contact has become formalized to the extent that a loosely constructed regime governs the interaction between the respective coast guards. The emphasis has been on developing bilateral cooperation, albeit with less urgency and demand in the case of the US, as geography and traffic numbers undoubtedly come into play. However, the growing focus on the Arctic in the US, in tandem with its chairmanship of the Arctic Council (2015-2017), is spurring new interest in developing cooperative mechanisms in the Bering Sea. This has taken place in spite of the limitations posed by the conflict with Russia over Ukraine. It also ties into the second reason for why the country's coast guards were deliberately sheltered in the aftermath of the annexation of Ukraine, namely their role as maritime stewards in a changing Arctic environment. 


\section{A. Osthagen}

\subsection{Ocean stewardship}

The bilateral maritime cooperation described above developed in tandem with the rise in activity levels in the maritime regions and the de-escalation that followed the end of the Cold War. Tasks such as fisheries inspections, emergency response and aid to navigation go hand-in-hand with an increase in civilian maritime traffic. As some of the other coast guards in the Arctic display - most noticeably the Canadian and the Swedish - the maritime tasks in question are not inherently of a military character. In the two cases examined here, however, the development of cooperative measures to deal with these tasks has been undertaken by military structures, as the coast guards in Norway, the US and Russia all belong to branches of the armed forces. ${ }^{62}$ Nevertheless, they undertake a number of different tasks, most of which are concerned with the protection of life and the environment.

Therefore, central to our understanding of the coast guards, is the concept of "soft" security tasks, moving away from a narrower definition of security revolving around the security of the state itself. ${ }^{63}$ Albeit part of the armed forces, the coast guards are arguably not primarily "hard" security actors. Instead, they serve as the police of the sea. For example, the Norwegian coast guard reports that it spends between 60 and 70 percent of its resources on fisheries inspections, solely. ${ }^{64}$ The coast guards in question enforce national legislation aimed at protecting the states' interests, while providing public services at sea. This does not discount the role they play in military operations, when needed. Yet, on an everyday basis, the coast guards perform a whole range of tasks, most of which are civilian in nature. Consequently, as their relationship with Russia came under scrutiny in both Norway and the US, maritime collaboration was considered indispensable. Had the cooperation only consisted of traditional military tasks, the states would have had both less of an incentive and a more difficult time justifying continued cooperation. In the cases examined here, however, the fact that the coast guards perform a whole range of civilian tasks has sheltered them from the larger deterioration in relations that took place in other parts of the countries' military relations.

Re-iterating this, US Coast Guard Vice Admiral Neffenger publically stated the need to engage more with Russia in the Arctic in 2014, after the annexation of Crimea ${ }^{65}$ One of main priorities in the US Arctic Council chairmanship from 2015 to 2017 also relates to stewardship of the Arctic Ocean, where the US Coast Guard has a marked role. ${ }^{66}$ Combined with active US engagement in finalizing the establishment of the Arctic Coast Guard Forum, these actions are, in part, efforts aimed at improving cooperation with Russia across the Bering Sea/Strait. ${ }^{67}$ Tellingly, Pomor - primarily a naval exercise between Norway and Russia in the Barents Seawas cancelled in 2014 and 2015; the Barents 2014 and 2015 exercises - which primarily focus on civilian emergency response - went ahead as planned, with both the Norwegian and Russian coast guards present. Such efforts showcase how both the US and Norway have made a clear distinction between low-level cooperative measures in the Arctic, and high-level politics related to sanctions imposed on Russia in response to the interference in Ukraine. 


\section{Conclusion}

Regional relationships with Russia in the Arctic cannot be sheltered from the deterioration of the overall relationship between Russia and the other Arctic states. Yet, most forms of cooperation on the coast guard level have been left untouched, while other forms of military contact were cancelled in the aftermath of Russia's annexation of Crimea in 2014. The decision to shelter certain areas of bilateral cooperation in the Arctic by both Norway and the United States provides an interesting study. The previous sections have described the development of maritime cooperation with Russia in two cases - the Bering and Barents Seas-with the intention of understanding this particular domain in a wider policy context. Moreover, by examining this specific contemporary event, we are able to better understand the role of coast guards and the structure of maritime collaboration at large.

Coast guard cooperation was maintained due to bilateral regime-building that has developed since the 1970s in both cases, in combination with the intrinsic relationship between coast guards and so-called "soft" security tasks. Having formalized cooperation through the exchange of information and joint exercises, the cost of tearing down decades of relationship-building in the Arctic was considered too high by both Norway and the US. This came in spite of both coast guards being part of the armed forces. In Norway's case, coast guard cooperation was interpreted as part of the country's twofold balancing act with Russia. Cancelling cooperation was thus placed in the context of highly developed neighbour relations involving measures such as information sharing and the exchange of fisheries officers. In the United States, less regime-building has taken place, although efforts to expand cooperative measures have increased in recent years. Still, the coast guard has actively worked to improve the relationship with Russia in the Bering Sea, in the context of growing American interest in the Arctic at large.

In both cases we see a similar end-result, namely a conscious decision to shelter regional maritime cooperation. This cooperation is subsequently seen in the context of a long-standing bilateral relationship with Russia, as a maritime neighbour, in what we call the "low politics" of the "high north." Maritime cooperation on day-today tasks in the coast guard domain does not constitute an area worth securitizing in the context of the broader relationship with Russia. ${ }^{68}$ Thus, this cooperation was kept separate from other military structures as tensions grew with Russia over Ukraine.

This article has highlighted the complexities of maritime cooperation between states, which cannot easily be reduced to dichotomous options. Instead, neighbouring states are dependent on dialogue across borders, separate from the domain of international diplomacy. In the end, the study of these two cases also shows how difficult it is to draw a distinct line between the civilian and military nature of maritime cooperation. Similarly, it showcases the breadth of bilateral cooperation and how the states' divergent structures of cooperation led to the same outcome, namely sheltering coast guards from the larger political situation. As such, coast 


\section{A. Osthagen}

guard cooperation in the Arctic serves as an example of how low-level cooperation can persist even as high-level politics deteriorates.

\section{NOTES}

1. Including countries adjacent to the Exclusive Economic Zone (EEZ): The United States, Japan, South Korea, North Korea, Kazakhstan, Azerbaijan, Georgia, Turkey, Ukraine, Poland, Lithuania, Estonia, Finland, and Norway.

2. For a good description/overview of the various security concepts with regards to the Arctic, see Hoogensen Gjørv et al. 2014.

3. The slogan "High North, Low Tension" was coined by the Norwegian Barents secretariat, and subsequently used by the Norwegian Foreign Ministry, to counter the idea of the Arctic as a region dominated by conflict and competing interests.

4. Henriksen and Ulfstein 2010, 1-2.

5. Hønneland 2013, 31; Kosmo 2010, 32-33.

6. Hønneland 2013, 21.

7. Byers 2013, 40; Hønneland 2013, 24-25.

8. Claes and Moe 2014, 102-110.

9. Stokke 2000 .

10. Eie 2011, 6-7.

11. Åtland 2015, 52 .

12. Hønneland 2013, 38.

13. Norwegian Directorate of Fisheries 2013.

14. Henriksen and Ulfstein 2010; Hønneland 2012b; Stokke 2014.

15. Mitchell 2013; Østhagen 2015a.

16. Norwegian Directorate of Fisheries 2013.

17. Ege 2012 .

18. Østhagen 2015a, 7-8.

19. Hønneland 2013.

20. Byers 2013; Kaczynski 2007, 2-3.

21. Named after the two foreign ministers from the United States of America and the Union of Soviet Socialist Republics who negotiated and signed the agreement.

22. Bailey 2011, 1-2; Delimitation Treaty 1990.

23. Kaczynski 2007, 3.

24. US Coast Guard 2014.

25. US Coast Guard 2007, 1; US Coast Guard 2010, 1-2.

26. Hønneland 2013, 59, 69.

27. Kaczynski 2007; US Coast Guard 2010.

28. NOAA 1988.

29. Bailey $2011,1-3$.

30. Dunlap 1994, 47.

31. USA/USSR 1989.

32. Pentland 2008.

33. Brigham 2013; Humpert 2014; Steinicke and Albrecht 2012.

34. Grady 2014; Ostrom 2012, 174; US Coast Guard 2013, 23.

35. Byers 2013, 157.

36. NOAA 2013.

37. On search and rescue (2011) and oil spill preparedness and response (2013) respectively.

38. US Official 2015.

39. National Security Council 2014, 24. 
40. In particular, see Åtland 2014 .

41. CBC News 2014; Østhagen 2014.

42. For a more detailed overview, see for example CBC News 2014; Mitchell 2014; and Sergunin 2014.

43. Lysvold 2010.

44. Østhagen 2015 b.

45. Klint 2014.

46. US Department of State 2015 b.

47. Jacobsen 2014.

48. Hoffman 1966, 882, 901.

49. Keohane and Nye 2012, 19, 93, 161; Ripsman 2005.

50. Mirovitskaya, Clark, and Purver 1993, 44-45; Østreng 1999, 76; Young 2010, 173.

51. Krasner 1983, 2.

52. See for example Mearsheimer 1995 and Strange 1982.

53. Lundestad and Tunsjø 2014, 393-394.

54. Huebert 2013.

55. Neumann et al. 2008.

56. Tamnes 2011.

57. Kraska 2011; Lundestad and Tunsjø 2014.

58. Conley and Rohloff 2015; Conley et al. 2012; Hilde 2013.

59. See for example Hønneland 2013; Hønneland 2012a; Hønneland 2012b; Stokke 2006; Stokke, Anderson, and Mirovitskaya 1999.

60. See for example chapter 6 in Byers 2013, or a brief overview in Kaczynski 2007.

61. See annual reports from the US Coast Guard, in particular US Coast Guard 2007; US Coast Guard 2010; US Coast Guard 2013.

62. The Russian Guard Coast is part of the Federal Security Service (FSB); the Norwegian Coast Guard is a separate branch of the Norwegian Navy; the United States Coast Guard is a separate institution under the Department of Homeland Security (in peacetime).

63. Hoogensen Gjørv et al. 2014.

64. Norwegian Government 2014.

65. See the testimony of Vice Admiral Neffenger from the US Coast Guard, July 23, 2014.

66. US Department of State 2015a. Former USCG Admiral Papp was appointed as the US Special Representative for the Arctic on July 16, 2014, and placed coast guard concerns at the top of this agenda during the US chairmanship of the Arctic Council.

67. US Official 2015.

68. See Buzan and Wæver (2003) for an extensive description of the concept of 'securitization', where political actors 'securitize' issues for a specific purpose.

\section{Bibliography}

Åtland, Kristian. "Interstate Relations in the Arctic: An Emerging Security Dilemma." Comparative Strategy 33, no. 2 (2014): 145-66.

Åtland, Kristian. Den russiske kystvakten mot 2020 - organisering, kapasiteter og operativ virksomhet [The Russian coast guard towards 2020 - organization, capacities and operations]. FFI-Rapport. Kjeller: Norwegian Defence Establishment (FFI), 2015.

Bailey, Kevin M. "An Empty Donut Hole: The Great Collapse of a North American Fishery." Ecology and Society 16, no. 2 (2011): 28.

Brigham, Lawson W. "The Fast-Changing Maritime Arctic." In The Fast-Changing Arctic: Rethinking Arctic Security for a Warmer World, ed. Barry Scott Zellen, 1-17. Calgary: Calgary University Press, 2013.

Buzan, Barry, and Ole Wæver. "Regions and Powers-The Structure of International Security." International Studies 7, no. 6 (2003): 564. Cambridge: Cambridge University Press. 


\section{A. Osthagen}

Byers, Michael. International Law and the Arctic. New York: Cambridge University Press, 2013.

CBC News. "Canada Boycotts Arctic Council Moscow Meeting over Ukraine.” CBC News, 2014. http://www. cbc.ca/news/canada/north/canada-boycotts-arctic-council-moscow-meeting-over-ukraine-1.2611964 (accessed June 6, 2015).

Claes, Dag H, and Arild Moe. "Arctic Petroleum Resources in a Regional and Global Perspective." In Geopolitics and Security in the Arctic: Regional Dynamics in a Global World, eds. Rolf Tamnes and Kristine Offerdal, 97-120. London: Routledge, 2014.

Conley, Heather, et al. A New Security Architecture for the Arctic: An American Perspective. CSIS Report. Washington, DC: Center for Strategic \& International Studies (CSIS), 2012.

Conley, Heather A, and Caroline Rohloff. The New Ice Curtain. Washington, DC: Center for Strategic \& International Studies (CSIS), 2015.

Delimitation Treaty. Agreement between the United States of America and the Union of Soviet Socialist Republics on the Maritime Boundary, 1 fune 1990. United Nations, 1999. http://www.un.org/Depts/los/ LEGISLATIONANDTREATIES/PDFFILES/TREATIES/USA-RUS1990MB.PDF (accessed June 1, 1990).

Dunlap, William V. 1994. 'A Pollock-Fishing Agreement for the Central Bering Sea.' IBRU Boundary and Security Bulletin (July 2014): 49-57.

Ege, Rune T. "Norge sier nei til russisk kystvakt-samarbeid." [Norway says no to Russian coast guard cooperation] $V G$, July 23, 2012. http://www.vg.no/nyheter/innenriks/forsvaret/norge-sier-nei-til-russisk-kystvakt-samarbeid/a/10059093/ (accessed July 23, 2012).

Eie, Harald Hermansen. "Sjøsikkerhet i det russiske nord" [Russian Emergency Preparedness in the Barents Sea in Theory and Practice]. IFS Insight 1/2011 (February 2011): 1-20.

Grady, John. "Former Coast Guard Commandant: U.S. and Russia Working Together In Arctic." USNI Nerws, 2014. http://news.usni.org/2014/09/30/former-coast-guard-commandant-u-s-russia-working-together-arctic (accessed June 6, 2015).

Henriksen, Tore, and Geir Ulfstein. "Maritime Delimitation in the Arctic: The Barents Sea Treaty." Ocean Development Eீ International Law 42, no. 1-2 (2010): 1-21.

Hilde, Paal S. "The 'New' Arctic - The Military Dimension.” fournal of Military and Strategic Studies 15, no. 2 (2013): 130-53.

Hoffman, Stanley. "Obstinate or Obsolete: The Fate of the Nation State and the Case of Western Europe." Daedalus 95, no. 3 (1966): 862-915.

Hønneland, Geir. Making Fishery Agreements Work: Post-Agreement Bargaining in the Barents Sea. Cheltenham: Edward Elgar, 2012a.

Hønneland, Geir. "Norsk-russisk miljø- og ressursforvaltning i nordområdene” [Norwegian-Russian Environmental and Resource Cooperation in the High North]. Nordlit 29, 2012. http://septentrio.uit.no/index. php/nordlit/article/view/2303/2134 (accessed July 7, 2015).

Hønneland, Geir. Hvordan skal Putin ta Barentshavet tilbake? [How shall Putin take the Barents Sea back?]. Bergen: Fagbokforlaget, 2013.

Hoogensen Gjørv, et al. eds. Environmental and Human Security in the Arctic. Abingdon, UK: Routledge, 2014.

Huebert, Rob. "U.S. Arctic Policy: The Reluctant Arctic Power." In The Fast-Changing Arctic: Rethinking Arctic Security for a Warmer World, ed. Barry Scott Zellen, 189-226. Calgary: Calgary University Press, 2013.

Humpert, Malte. Arctic Shipping: An Analysis of the 2013 Northern Sea Route Season. Washington, DC: The Arctic Institute, 2014. http://www.thearcticinstitute.org/2014/10/NSR-Shipping-Report.html (accessed May 13, 2015).

Jacobsen, Håkon. "Kystvakten fortsetter samarbeidet med russland” [Coast guard continues cooperation with Russia]. NRK. 2014. http://www.nrk.no/nordland/fortsetter-samarbeid-med-russland-1.11856338 (accessed May 6, 2015).

Kaczynski, Vlad M. "US-Russian Bering Sea Marine Border Dispute: Conflict over Strategic Assets, Fisheries and Energy Resources.” Russian Analytical Digest 20 (May 1, 2007): 2-6.

Keohane, Robert O, and Joseph S. Nye. Power and Interdependence. 4th ed. New York and London: Longman, 2012.

Klint, Chris. "U.S. Coast Guard Joins Search for 54 Fishermen after Bering Sea Sinking.” KTUU-TV, 2014. http://www.ktuu.com/news/news/coast-guard-monitors-bering-sea-sinking-of-60person-fishing-vessel/ 30000826 (accessed May 16, 2015).

Kosmo, Svein. Kystvaktsamarbeidet Norge-Russland. En fortsettelse av politikken med andre midler? [Coast guard cooperation with Russia: a continuation of politics with different tools?]. Forsvarets Stabsskole. Oslo: Norwegian Joint Staff College, 2010. 


\section{Maritime Cooperation with Russia in the Arctic}

Kraska, James. "The New Arctic Geography and U.S. Strategy." In Arctic Security in an Age of Climate Change, ed. James Kraska, 244-66. New York: Cambridge University Press, 2011.

Krasner, Stephen D. International Regimes. Ithaca: Cornell University Press, 1983.

Lundestad, Ingrid, and Øystein Tunsjø. "The United States and China in the Arctic." Polar Record FirstView 259 (2014): 1-12.

Lysvold, Susanne. "Russland og Norge klare for storøvelse" [Russia and Norway ready for large exercise]. NRK, June 1, 2010. http://www.nrk.no/nordland/russland-og-norge-klare-for-ovelse-1.7148721 (accessed May 13, 2015).

Mearsheimer, John J. “The False Promise of International Institutions." International Security 19, no. 3 (1995):5-49.

Mirovitskaya, Natalia S, Margaret Clark, and Ronald G. Purver. "North Pacific Fur Seals: Regime Formation as a Means of Resolving Conflict." In Polar Politics: Creating International Environmental Regimes, eds. Oran Young and Gail Osherenko, 22-55. New York: Cornell University Press, 1993.

Mitchell, James R. The Canadian Coast Guard in Perspective: A Paper Prepared for Action Canada. Ottawa: Action Canada, 2013. http://www.actioncanada.ca/en/wp-content/uploads/2013/08/Canadian-Coast-Guard-InPerspective_EN.pdf (accessed June 5, 2015).

Mitchell, Jon. "Russia's Territorial Ambition and Increased Military Presence in the Arctic." Foreign Policy fournal April 23, 2014. http://www.foreignpolicyjournal.com/2014/04/23/russias-territorial-ambition-andincreased-military-presence-in-the-arctic/ (accessed June 5, 2015).

National Security Council. Implementation Plan for the National Strategy for the Arctic Region. Washington, DC: White House, 2014. https://www.whitehouse.gov/sites/default/files/docs/implementation_plan_for_the_ national_strategy_for_the_arctic_region_-_fi.pdf (accessed June 5, 2015).

Neffenger, Peter V. Testimony of Vice Admiral Peter V. Neffenger Vice Commandant on Implementing U.S. Policy in the Arctic. House Coast Guard and Maritime Transportation Subcommittee. US. Washington D.C: Department of Homeland Security, 2014.

Neumann, Iver B, et al. Norge og alliansene: gamle tradisjoner, nytt spillerom [Norway and the alliances: old traditions, new room for maneuver]. Oslo: Norwegian Institute of International Affairs (NUPI), 2008.

NOAA. Agreement Between the Government of the United States of America and the Government of the Union Of Soviet Socialist Republics on Mutual Fisheries Relations. 1998. http://www.nmfs.noaa.gov/ia/bilateral/docs/ US-Russia_ICC_IA_Book.pdf (accessed June 5, 2015).

NOAA. "Strengthening U.S.-Russia Cooperation on Fisheries." NOAA Fisheries, 2013. http://www.nmfs.noaa. gov/ia/slider_stories/2013/04/us_russia.html (accessed June 5, 2015).

Norwegian Directorate of Fisheries. Memorandum om samarbeidsordninger om kontroll mellom Det norske fiskeridirektoratet, Den norske kystvakten, Rosrybolovstvos territorielle administrasjon for Barentshavet og Kvitsjøen og Grensedirektoratet $i$ Russlands føderale sikkerhetstieneste i Murmansk [Memorandum of understanding of inspections between the Norwegian Directorate of Fisheries, the Norwegian Coast Guard, the Rosrybolovstov's territorial administration for the Barents Sea and the White Sea, and the Border Directorate in the Russian Federal Security Service in Murmansk]. Murmansk: Norwegian Government, 2013.

Norwegian Government. "Kystvakten" [The coast guard]. Ulovlig fiske [Illegal fisheries], 2014. https://www. regjeringen.no/no/tema/mat-fiske-og-landbruk/fiske-og-havbruk/ulovlig-fiske/kystvakten/id438806/ (accessed June 21, 2015).

Østhagen, Andreas. "Ukraine Crisis and the Arctic: Penalties or Reconciliation?" The Arctic Institute, April 30, 2014. http://www.thearcticinstitute.org/2014/04/impact-of-ukraine-crisis-on-Arctic.html (accessed April 30, 2014).

Østhagen, Andreas. "Coastguards in Peril: A Study of Arctic Defence Collaboration." Defence Studies 15, no. 2 (2015a): 143-60.

Østhagen, Andreas. The Arctic Coast Guard Forum: Big Tasks, Small Solutions. The Arctic Institute, November 3, 2015b. http://www.thearcticinstitute.org/2015/11/the-arctic-coast-guard-forum-big-tasks.html (accessed November 18, 2015).

Østreng, Willy. "Strategic, Legal and Political Implications of International Shipping on the NSR." In The 21st Century - Turning Point for the Northern Sea Route?, ed. Claes L. Ragner, 71-87. Oslo: Kluwer Academic, 1999.

Ostrom, Thomas P. The United States Coast Guard and National Defence: A History from World War I to the Present. Jefferson, NC: McFarland, 2012.

Pentland, William. “Alaska's Waters Quietly Reopen To Drilling.” Forbes. 2008. http://www.forbes.com/2008/ 08/04/alaska-oil-energy-biz-energy-cx_wp_0805alaska.html (accessed June 5, 2015).

Ripsman, Norrin M. "False Dichotomies: Why Economics Are High Politics." In Guns and Butter: The Political Economy of International Security, ed Peter J. Dombrowski, 288. Boulder: Lynn Rienner, 2005. 


\section{A. Osthagen}

Sergunin, Alexander. "Four Dangerous Myths about Russia's Plans for the Arctic." Russia Direct, November 25, 2014. http://www.russia-direct.org/analysis/four-dangerous-myths-about-russias-plans-arctic (accessed June 5, 2015).

Steinicke, Stefan, and Sascha Albrecht. Search and Rescue in the Arctic. Working Paper. Vol. 2012/05. Berlin: Stiftung Wissenschaft und Politik, 2012.

Stokke, Olav Schram. "Sub-Regional Cooperation and Protection of the Arctic Marine Environment: The Barents Sea." In Protecting the Polar Marine Environment: Law and Policy for Pollution Prevention, ed. Davor Vidas, 124-38. Cambridge: Cambridge University Press, 2000.

Stokke, Olav Schram. "Examining the Consequences of Arctic Institutions." In International Cooperation and Arctic Governance: Regime Effectiveness and Northern Region Building, ed. Olav Schram Stokke and Geir Hønneland, 13-26. New York: Routledge, 2006.

Stokke, Olav Schram. "International Environmental Governance and Arctic Security." In Geopolitics and Security in the Arctic, ed. Rolf Tamnes and Kristine Offerdal, 121-46. Abingdon: Routledge, 2014.

Stokke, Olav Schram, Lee G. Anderson, and Natalia S. Mirovitskaya. "The Barents Sea Fisheries." In The Effectiveness of International Environmental Regimes: Causal Connections and Behavioral Mechanisms, ed. Oran R. Young, 91-155. Cambridge, MA: The MIT Press, 1999.

Strange, Susan. "Cave! Hic Dragones: A Critique of Regime Analysis.” International Organization 36, no. 2 (1982): 479 .

Tamnes, Rolf. "Arctic Security and Norway." In Arctic Security in an Age of Climate Change, ed. James Kraska, 47-64. New York: Cambridge University Press, 2011.

US Coast Guard. “17th Coast Guard District Enforcement Report.” Juneau, AK, 2007. http://www.npfmc.org/ wp-content/PDFdocuments/resources/USCG/DEC07USCG.pdf (accessed May 3, 2015).

US Coast Guard. "17th Coast Guard District Enforcement Report.” Juneau, AK, 2010. http://www.npfmc.org/ wp-content/PDFdocuments/resources/USCG/OCT10USCG.pdf (accessed May 3, 2015).

US Coast Guard. United States Coast Guard Arctic Strategy. Washington, DC: US Coast Guard, 2013.

US Coast Guard. “August: Daily Chronology of Coast Guard History.” United States Coast Guard. Daily Chronology: United States Coast Guard, 2014. http://www.uscg.mil/history/Chron/Chronology_Aug.asp (accessed May 3, 2015).

US Department of State. One Arctic-Arctic Council U.S. Chairmanship 2015-2017, 2015a. http://www.arcticcouncil.org/images/PDF_attachments/US_Chairmanship/Chairmanship_Brochure_2_page_public.pdf (accessed May 3, 2015).

US Department of State. United States and Russia Sign Agreement to Prevent Illegal Fishing. Press Release, 2015b. http://www.state.gov/r/pa/prs/ps/2015/09/246833.htm (accessed May 3, 2015).

US Official. Interview with US Official. Oslo, May 27, 2015.

USA/USSR. Agreement between the Government of the United States of America and the Government of the Union of Soviet Socialist Republics Concerning Cooperation in Combatting Pollution in the Bering and Chukchi Seas in Emergency Situations. 1989. http://dec.alaska.gov/spar/ppr/plans/uc/mou/Kp-US_USSR_89.pdf (accessed May 3, 2015).

Young, Oran R. "Arctic Governance-Pathways to the Future." Arctic Review on Law and Politics 1, no. 2 (2010): 164-85. 